\title{
Composition and Medicinal Uses of Five Plant Products Traditionally used as Blood Builders in South East Nigeria- A Review [1]
}

\section{Ojimelukwe PC*}

Department of Food science and technology, Michael Okpara University of Agriculture, Umudike, Abia state, Nigeria

*Corresponding Author: Ojimelukwe PC, Department of Food science and technology, Michael Okpara University of Agriculture, Umudike, Abia state, Nigeria.

Received: May 24, 2019; Published: July 08, 2019

DOI: $10.31080 /$ ASNH.2019.03.0359

\begin{abstract}
Anaemia is a very common global public health problem which normally aggravates other diseases such as malaria. It accounts for low work output, high frequencies of ill health and high mortality rates. Weakness is the commonest symptom associated with anaemia. Traditional practices associated with anaemia control primarily focus on the use of perceived blood builders to combat weakness and replace lost blood. Solanum aethiopicum, Sida rhombifolia, Irvinia gabonensis, Fiscus capensis and Curcubita maxima are some of the plant products traditionally perceived as blood builders in South East Nigeria. The plant products are found in several parts of the world but were used as traditional blood builders in South east Nigeria and are presently neglected. The chemical composition, morphological characteristics, and medicinal uses of the plant products associated with traditional concepts about blood building are reviewed in this paper. The iron content and select vitamin and minerals in parts of the plant products used traditionally as blood builders were determined and compared with available data in literature. Solanum aethiopicum, Sida rhombofolia and Curcubita maxima have been identified as good sources of iron. Solanum aethiopicum, Sida rhombofilia and Fiscus capensis are rich in pro-vitamin A, while Solanum aethiopicum and Curcubita maxima are rich sources of vitamin C. Values of minerals and vitamins from various authors were compared. Some of the perceived blood builders are rich in iron and other nutrients that are very relevant to blood formation and oxygen transport. The finding highlighted in this report should revive interest in the use of these crops and motivate research interest in other plant products that are potential blood builders for combating anaemia.
\end{abstract}

Keywords: Traditional Blood Builders; Composition; Solanum aethiopicum, Curcubita maxima; Sida rhombifolia; Fiscus capensis; Irvingia gabonensis; Medicinal Uses

\section{Introduction}

Anaemia is a major cause of illness, low work output and death. It may be caused by low amounts of haemoglobin, evidenced by reduced total number of red blood cells or reduced number of healthy red blood cells. It is a leading cause of disability and one of the most serious public health problems. Many factors cause anaemia but iron deficiency and infections are the most common [1]. These factors include; nutritional deficiencies of vitamin $A$ and B12, folate, riboflavin, blood disorders like thalassemia and haemoglobinopathies which are characterized by abnormal haemoglobin. Iron is essential to the human body, aiding the formation of haemoglobin (the protein in the blood responsible for oxygen transport).

Strategies already put in place to alleviate anaemia include food fortification and dietary diversification with iron [2]. They are important measures which have been useful to prevent iron deficiency anaemia, especially in the vulnerable groups such as pregnant women and children. A number of strategies are used to deliver additional iron to humans, but food fortification has the greatest potential to improve the iron status of the largest number of people [3]. Ferrous fumarate, ferrous succinate and small particle size iron are suitable iron fortificants for infant cereals [4]. Infant cereals are widely fortified in developed countries and this has resulted in a definite reduction in anaemia [5]. World Health Organization recommended that all pregnant women receive iron supplements of $60 \mathrm{mg}$ daily combined in a pill, which also contains $400 \mu \mathrm{g}$ folic acid [2].

Red meat is one of the richest sources of iron. Other good sources of iron include the liver, fish, poultry and blood. Animal foods contain iron in a form that can be directly absorbed in the human digestive tract unlike plant foods. Sometimes iron in plant foods is bound by antinutrients such as tannins and phytates and are made biologically unavailable. Many food supplements contain iron. In the traditional settings in South East Nigeria, there are known 
plant products which are quickly sourced whenever anaemia is suspected. Water extracts of these plant products are administered to the patient and recovery is expected within a short time frame. For many of these plant products there is no clear scientific documentation and proof of their ability to contain significant amounts of iron, nor the mechanism by which they are believed to restore the haemoglobin content of the body and prevent anaemia or restore anaemia patients to normalcy. There is need to understand the science of traditional health promoting practices and ensure that beneficial health promoting foods are not neglected.

This paper is a review of the health benefits of five local plant products believed in the traditional settings of South East Nigeria to possess the ability to increase the haemoglobin content of the human blood within a short period. In local settings in South East Nigeria, they are referred to as blood builders. The paper reviews the health benefits of the plant products in relation to their micronutrient composition with particular emphasis on iron.
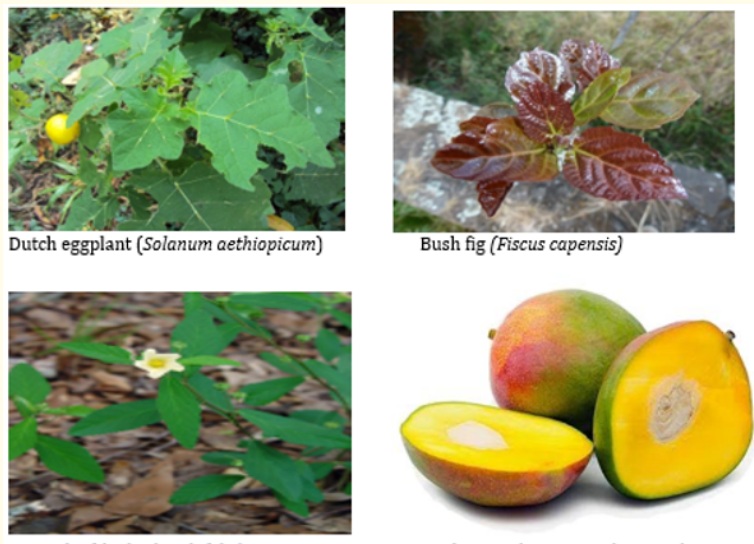

Arrow leaf (Sida rhombifolia)
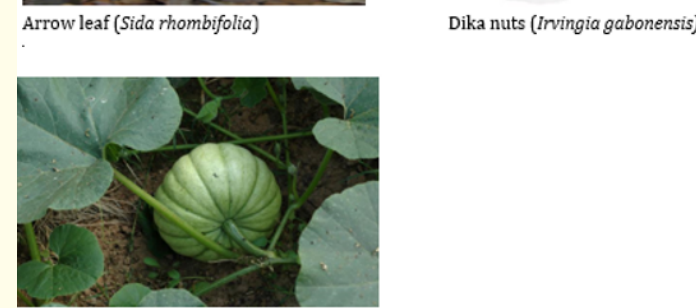

Figure 1: Plant products traditionally perceived as blood builders.

\begin{tabular}{|l|c|c|}
\hline $\begin{array}{c}\text { Indigenous name } \\
\text { (Igbo) }\end{array}$ & English name & Botanical name \\
\hline Akwukwoanara & Dutch eggplant & Solanum aethiopicum \\
\hline Obinwoke & Arrowleaf & Sida rhombifolia \\
\hline Ogbono & African mango & Irvingia gabonensis \\
\hline Akwakwobara & Bush fig & Fiscus capensis \\
\hline Ugbogoro & Pumpkin & Cucurbita maxima \\
\hline
\end{tabular}

Table 1: Plant products traditionally used as blood builders.

\section{Methods}

Purposeful surveys were carried out in five states of South East Nigeria to identify plant products used as blood boosters in the traditional settings. Only plant products mentioned by at least ten persons from the localities were further identified. In each community, two women assisted the researcher to collect and identify some of the wild and domesticated fruits and vegetables that are traditionally regarded as blood builders. The fruits and vegetables identified were analysed for select vitamins and minerals related to haemoglobin formation and metabolism (Vitamins $\mathrm{A}_{1} \mathrm{~B}_{1}, \mathrm{~B}_{2}, \mathrm{~B}_{3}$ and $\mathrm{B}_{9}$; zinc). Determinations were carried out using AOAC standard methods [6]. A detailed literature search was conducted to collate information on the nutrient composition and medicinal uses of the plant products traditionally used as blood builders. The search terms were: morphology, general uses, medicinal uses, chemical composition for each of the plant products.

\section{Results}

Solanum aethiopicum

Plant Morphology and General Uses of Solanum aethiopicum

Solanum aethiopicum belongs to the family Solanaceae. It has over 1000, many of which are indigenous to Africa [7]. Some of them are valuable crops while others are poisonous. Up to 25 species of Solanum are grown in Nigeria. Some are domesticated, while others are wild. The leaves and or fruits may be eaten as vegetable. Both the leaves and fruits may also be used in traditional medicine. The African eggplant (S. aethiopicum L.) is widely cultivated in $\mathrm{Ni}$ geria and across the African continent. S. aethiopicum is also grown to a significant extent in some parts of Europe [8]. The vegetative and fruit morphologies of $S$. aethiopicum vary. Variations in diameter of leaves, branching of stalks fruit shapes and colours are easily observed. Cultivation and use of $S$. aethiopicum is increasing in parts of West Africa [9]. It can be planted at any time of the year. Even in tropical dry seasons, it can be grown in hilly areas where morning dews and mists are experienced. Sometimes, it is difficult to obtain viable seeds for germination.

Local names for Solanum aethiopicum in Nigeria include: garden egg (Hausa: Dauta; Igbo: afufa or añara; Yoruba: Igbagba) [10]. It is a highly valued constituent of the Nigerian foods and indigenous medicines; it is frequently consumed by both rural and urban families. The eggplants form part of the traditional Sub-Saharan African culture. The fruits, are offered as a welcome gesture during visits, marriages, funerals and other social events. They are eaten raw and may also be boiled or fried and used as ingredient of stews, soups and vegetable sauces. The fruit of the plant may eaten both raw and cooked and is becoming more popular as a cultivated crop. In $\mathrm{Ni}-$ geria, Igbo people use it as a substitute for kolanut. The leaves of Solanum aethiopicum are eaten as a leaf vegetable and are actually more nutritious than the fruit. S. aethiopicum fruits are more palat- 
able if harvested while they are still green, before the skin changes colour and becomes hard to chew. The bitterness depends on the variety and constituents. Some varieties have a sweet flavour while others are very bitter. When the berries mature, they turn bright red because of high carotene content. Garden egg is sometimes used to make a tomato based sauce which can be used to eat yam. Solanum aethiopicum is used as an ornamental plant in Asia.

The fruits of the African eggplant may be striped or multi-coloured. They may be coloured white, cream, yellow, green, lime, orange, pink, red, plum, burgundy, lavender, violet, purple, and dusky black [11]. The fruits are more palatable if picked when they are still tender. The African eggplant is a valuable and regular source of food, in addition to its use for medicinal purposes. It is beneficial for diabetes, bronchitis, asthma, dysuria, dysentery, etc. [12].

\section{Medicinal Uses of Solanum aethiopicum}

The plant has a wide range of local medicinal applications. Its uses in indigenous medicine range from weight reduction to treatment of several ailments including asthma, allergic rhinitis, nasal catarrh, skin infections, rheumatic disease and pains of swollen joints, constipation and dyspepsia [12].

The plant has been used in local foods and traditional medicines; for instance, different researchers have reported significant analgesic, anti-inflammatory, anti-asthmatic, anti-glaucoma, hypoglycemic, hypolipidemic and weight reduction effects of eggplants on test animals and humans [13]. Chemical substances in the plant, such as fibre, ascorbic acid, phenols, anthocyanin, glycoalkaloids and $\alpha$-chaconine are responsible for its pharmacological properties.

\section{Chemical constituents of Solanum aethiopicum.}

The chemical composition of Solanum aethiopicum is shown in Table 2.

\begin{tabular}{|l|c|}
\hline \multicolumn{1}{|c|}{ Composition } & Values \\
\hline Moisture & $89.72 \mathrm{~g}$ \\
\hline Protein & $2-24 \mathrm{~g}$ \\
\hline Fat & $0.52 \mathrm{~g}$ \\
\hline Ash & $0.87 \mathrm{~g}$ \\
\hline Crude fibre & $2.96 \mathrm{~g}$ \\
\hline Carbohydrate & $4.14 \mathrm{~g}$ \\
\hline Calcium & $497 \mathrm{mg}$ \\
\hline Magnesium & $1.98 \mathrm{mg}$ \\
\hline Iron & $1.02 \mathrm{~g}$ \\
\hline
\end{tabular}

Table 2: Chemical composition of Solanum aethiopicum.
Proximate composition of Solanum aethipioicum L (per 100g) showed a lot of variation in the protein content of different species ranging from as low as $2 \mathrm{mg} / 100 \mathrm{~g}$ to $24 \mathrm{mg} / 100 \mathrm{~g}$ [14]. Other researchers who have worked on this fruit found similar nutrient contents (except for protein) including $1.98 \mathrm{mg}$ of magnesium as well as phytochemicals like sesquiterpenoids and phenols [15].

\section{Sida rhombifolia}

Morphology and General Uses

Sida rhombifolia, often referred to as Arrow leaf sida,belongs to the Kingdom Plantae; Order Malvales; Family Malvaceae; Genus Sida and species: Sida rhombifolia. It is a perennial or sometimes annual plant in the Family Malvaceae. Its common names include rhombus-leaves sida, Paddy's lucerne, jelly leaf, arrow leaf sida, big Jack, bloom weed, broomstick, coffee bush, common sida, country mallow, Cuban jute, flaxweed, Indian hemp, Paddy's lucerne, Pretoria sida, Queensland hemp, rhomboid ilima, shrub. Synonyms include Malva rhombifolia [16]. It is used in Ayurvedic medicine, where it is known as kurumthotti.

The stems may be erect or sprawling and branched. It grows to a height of 50 to 120 centimetres. The lower section is woody. Leaves are diamond shaped and dark green. The leaves are arranged alternately along the stem, 4 to 8 centimetres long, with relatively short petioles (when compared with the length of the leaves). The leaves are entire. The petioles bear small tiny flowers at the stipules of their bases that may be long, creamy to orange-yellow. The flowers may be reddish at the centre. Flower stalks bear single flowers that are found between the stems and the leaf petioles. The fruit is capsular and has 8 to 10 segments. The plant blooms throughout the year. S. rhombifolia is commonly found on waste ground, such as roadsides and rocky areas, stock camps or rabbit warrens. It is rather unpalatable to livestock [17].

\section{Medicinal Uses of Sida rhombifolia}

S. rhombifolia has many medicinal applications in India. The leaves may be pounded and used to relieve swelling, the fruits are used to relieve headache, the mucilage is used as an emollient, and the root is used to treat rheumatism [18]. The root is also used to treat infant asthma. Australian Aborigines use the herb to treat diarrhoea. Leaves are smoked in Mexico and a stimulating tea is prepared from it [19]. The cytotoxic and antibacterial activities of Sida rhombifolia leaves have been investigated. The ethyl acetate extract showed cytotoxicity with LC50 values (5.41 ppm) comparable to the reference standard, gallic acid. The extracts showed weak antibacterial activity against both gram-positive and gram-negative test organisms. Sida rhombifolia (L.) is widely used in Ayurvedic medicine for the treatment of fever and as a diuretic (Pandanus database of Indian plants "Sida rhombifolia"). The antioxidant po- 
tentials of ethanol extract of roots, stems, leaves, and whole plant were studied [20]. Total polyphenols were determined. Assays for free radical scavenging, reducing power, superoxide anion scavenging, nitric oxide scavenging, and anti-lipid peroxidation, were conducted. Antioxidant activities were compared with standard antioxidants such as butylated hydroxyl anisole and $\alpha$-tocopherol acetate. Extracts were found to be good scavengers of 1, 1-diphenyl-2-picrylhydrazyl radical. The roots were more potent antioxidants than the leaves, which were still more potent than the whole plant and the stem. All extracts of this plant were effective free radical scavengers. They had high reducing power, and superoxide scavenging activity. However, only the root extract inhibited lipid peroxidation in rat liver and brain homogenate. The antioxidant properties of all parts of the plant were concentration dependent. The highest antioxidant activity was observed in the root extract. This study indicates that $\mathrm{S}$. rhombifolia is a good source of natural antioxidants.

\section{Constituents of Sida rhombifolia}

Arrow leaves: Chemical analysis revealed that arrow leaves (S. rhombifolia) contain reasonable amounts of nutrients [20].

\begin{tabular}{|l|c|}
\hline & g/kg \\
\hline Protein & $74-374$ \\
\hline Carbohydrates & $94-475$ \\
\hline Fibre & $33-167$ \\
\hline Fat & $14-71$ \\
\hline Ash & $16-81$ \\
\hline
\end{tabular}

Table 3: Chemical composition of Sida rhombifolia leaves.

Sida leaves are rich in nutrients (see Table 3). It was also reported that the root contained 450 ppm alkaloids including ephedrine and saponin [20]. Another source reported alkaloid content of 0.1 percent in the root and the presence of choline, pseudoephedrine, beta-phenethylamine, vascin, hipaphorine and related indole alkaloids [21]. Perhaps because of these chemicals, arrow leaf Sida is unpalatable to cattle.

\section{Irvingia gabonensis}

Morphology and general uses

Irvingia gabonensis belongs to the genus Irvingia. Its common names are; wild mango, African mango, bush mango. Local names include dika or ogbono. African bush Mango is also known as African wild mango, Irvingia, Dika (dikanut, dikabread tree), Odika, Ogbono, Sweet bush mango, Bush mango and Iba-tree. It bears edible mango-like fruits. Dika nuts contain significant amounts of fat and protein. Irvingia gabonensis is predominant in the humid forests of North Angola, Congo, DR Congo, Nigeria, Côte d'Ivoire and Southwest Uganda. It is domesticated in South-east Nigeria,South-west Nigeria, southern Cameroon, Côte d'Ivoire, Ghana, Togo, and Benin.
Dika is commonly found in canopied jungles, and semi-deciduous forests. It grows at altitudes from 200-500 m (660-1,640 ft.) It requires annual rainfalls from $120-150 \mathrm{~cm}$ (47-59 in); temperature ranges of $20-38{ }^{\circ} \mathrm{C}\left(68-100{ }^{\circ} \mathrm{F}\right)$. It requires deep soils for proper growth (>150 cm or $59 \mathrm{in})$ with a moderate fertility and good drainage. Optimum range for $\mathrm{pH}$ is from 4.5 to 7.5 [22].

Dika fruits may be eaten fresh. The fruits may be used to manufacture jelly, jam, juice or wine. Black dye for cloth coloration can be made from the pulp. Seeds, also called dika nuts, may be eaten raw or roasted. Most often, however they are pounded and pressed to produce edible fat used for cooking. The oil may be used to produce soap or cosmetics. Cattle feed may be produced using the defatted cake. It can also be used as a soup thickener. Seeds can be ground or crushed and used as a thickening and flavouring agent in soups and stews. They can also be made into a cake called "dika bread" for preservation. The sweet pulp can be juiced or used for making smoothie, jelly, jam and wine. The seeds can be pressed for vegetable oil or margarine. The dried seeds can be ground and used for preparing soup, stew, Gabon chocolate and dika bread. The hard wood from the plant is used for heavy construction work such as making ships' decks or railway ties. Dead branches are used as firewood. The trees provide shade for other crops, especially cocoa and coffee. They are also used to reduce erosion. Cities have started using them to shade streets, as shelter belts, or for beautification. Dika seeds are sold within various parts of Africa [22].

\section{Medicinal Uses of Irvingia gabonensis}

African mango seed lowers cholesterol levels and improves the management of diabetes and obesity. It has antioxidant properties and increases gastrointestinal activity.

Several studies have been carried out to ascertain the medicinal and nutritional benefits of Irvingia gabonensis. Anegbeh., et al. [22] observed that the Irvingia fruits are used for treating several diseases. Obese people who eat Dika seeds have reduced fasting blood glucose levels [23]. They evaluated the antidiabetic properties of Irvingia gabonensis leaf and bark extracts on alloxan induced diabetic rats. They observed its beneficial effects for weight loss, reduction of bad cholesterol; improvement of gastrointestinal activity and as an antioxidant.

The African mango is said to have antibacterial, astringent, analgesic, anti-inflammatory properties. Traditionally, African mango has been used to treat a variety of conditions, including diarrhoea, wounds, dysentery, yellow fever and tympanic membrane infections. It might also be helpful in lowering blood sugar levels. In addition, African mango is used for weight loss because it may decrease appetite and stimulate the body to burn fat stores for energy. The fibre content provides bulk, improving bowel function and aiding detoxification pathways. Irvingia gabonensis fruit can 
be eaten as fresh fruit. African mango seed is a good source of several minerals, including magnesium, iron and potassium, while the pulp is high in calcium and vitamin C. It contains 18 amino acids, which are the building blocks of proteins. African mango is a good source of palmitic and lauric fatty acids. Researchers observed low incidences of obesity, diabetes, and related diseases in a particular region of Africa. Further research revealed that the people of this region used Irvingia as a soup thickener an average of ten times per week. Eventually, this led to the development of a bush mango extract [24]. Specifically, bush mango may help to reduce weight; reduce serum cholesterol; reduce plasma glucose level; prevent and treat bacterial and fungal infections; relieve pain; enhance drug tablet/ drug release and disintegration properties.

\section{Constituents of Irvingia gabonensis}

African mango Dika nuts: The seeds contain more non- structural carbohydrates than the mesocarp. The edible seed contains substantial amount of nutrients. Several studies have assessed the chemical properties of the kernels or seeds in African mango. Eighteen (18) amino acids were identified in fresh African mango seeds. It is a good source of nutrients, vitamins and minerals such as calcium, magnesium, potassium, sodium, phosphorus and iron.

Table 4 shows the chemical composition of the full fat kernel and the edible portion of Irvingia gabonensis [25]. Edible part of the seed contains significant amounts of nutrients [25]. It contains 97.61\% saturated fat; $2.12 \%$ monosaturated fatty acids and $0.27 \%$ polyunsaturated fatty acids. The fat is rich in lauric acid (27.63\%); and myristic acid (61.68\%). Ardabili., et al. [46], reported fatty acid composition of myristic acid: $33-37 \%$; lauric acid: $20-59 \%$; oleic acid: $1-11 \%$; palmitic acid: $2 \%$; stearic acid: $1 \%$. I gabonensis fatty acid profile is similar to that of palm kernel oil and coconut oil. I. gabonensis kernel fat increases the amount of HDL-cholesterol in blood and liver lipids. Lauric and myristic acids are metabolized faster through portal absorption. The pulp of I. gabonensis contains $81 \mathrm{~g}$ water; $15.7 \mathrm{~g}$ carbohydrate; $0.9 \mathrm{~g}$ protein; $2 \mathrm{~g}$ fat; $40 \mathrm{mg}$ phosphorus; $20 \mathrm{mg}$ calcium; $7 \mathrm{mg}$ vitamin $\mathrm{C}$ and $2 \mathrm{mg}$ iron. The flavour compounds found in the fruit pulp include zingiberene; cinnamic acid; dodecanal and dodecanol.

\section{Fiscus capensis}

Morphology and general uses

Ficus capensis Thunb. Is a member of the Moraceae family. It may be found in tropical rain forest zones and grassy woodlands. The common names are Cape fig and broom cluster fig. The plant has ovate to elongated elliptic leaves, about 7.5 - $15 \mathrm{~cm}$ long and 5 $-10 \mathrm{~cm}$ wide. The leaves have a blunt apex which are sometimes rounded. The leaf base is occasionally cuneate or slightly unequally asymmetrical. They are leathery, dark green, with glabrous surfaces and no epidermal hairs. The margin could be dentate, wavy or entire. It has densely clustered fruits found along short branched shoots on the main stem and older branches. Fresh foliage has a papery red colour. Older trees have darker and rough bark. Solitary or paired figs may found among the leaves. The individual figs have short stalks 2.5 - $3 \mathrm{~cm}$ long (48). The ripe figs are sometimes eaten and are also made into jams, puddings and preserves, young leaves and shoots are occasionally cooked and eaten as vegetable [26].

\section{Medicinal uses of Fiscus capensis}

This plant product is regarded as a symbol of fertility in many traditional settings. Magical properties are often ascribed to the tree in addition to its being regarded as a symbol of fertility [27]. In Nigeria, F. capensis has been used for the treatment of dysentery and wound dressing [28]. It is also used in circumcision, leprosy, epilepsy, rickets, infertility, gonorrhoea, oedema, respiratory disorders and as an emollient [29]. The leaves and stems bark of the plant have inhibitory effects against Esherichia coli and Shigella species [30]. It is also used in herbal medicine to treat threatened abortion [31]. Igoli., et al. [32] reported the ethno-medicinal use of the leaves of Ficus capensis Thunb. (Moraceae) after decoction in treating diarrhoea. The plant leaves is used in treating dysentery, oedema, epilepsy and rickets. There are reports on the antimalari$\mathrm{al}$, antibacterial and anti-ulcer activities of the leaves [32].

\section{Chemical constituents of Fiscus capensis}

Table 5 shows the chemical composition of the stem bark of Fiscus capensis. It contains alkaloids, anthraquinones; phlobatanins, tannins, cardiac glycosides and flavonoids in moderate amounts [32].

\begin{tabular}{|l|c|}
\hline Moisture & $9.80 \mathrm{~g}$ \\
\hline Ash & $15.6 \%$ \\
\hline Protein & $3.64 \%$ \\
\hline Crude fat & $1.92 \%$ \\
\hline Fibre & $16.37 \%$ \\
\hline Carbohydrate & $52.66 \%$ \\
\hline Energy & $242.44 \mathrm{~kg}$ \\
\hline Calcium & $18.39 \mathrm{mg} / \mathrm{kg}$ \\
\hline Sodium & $16.11 \mathrm{mg} / \mathrm{kg}$ \\
\hline Potassium & $52.50 \mathrm{mg} / \mathrm{kg}$ \\
\hline Magnesium & $6.09 \mathrm{mg} / \mathrm{kg}$ \\
\hline Iron & $2.40 \mathrm{mg} / \mathrm{kg}$ \\
\hline Zinc & $2.32 \mathrm{mg} / \mathrm{kg}$ \\
\hline Manganese & $5.01 \mathrm{mg} / \mathrm{kg}$ \\
\hline
\end{tabular}

Table 5: Chemical composition of the stembark of Fiscus capensis.

\section{Curcubita maxima}

Morphology and general uses

Pumpkins belong to the family Cucurbitaceae, which consists of five genera: Citrullus (e.g. water melon and wild colocynths); $\mathrm{Cu}$ cumis (e.g.cucumbers, gherkins and melons): Lagenaria (gourds): 
Sechium (chayote) and Curcubita. The genus Curcubita includes five species: C. maxima; C. pepo; C. moschata: C. ficifolia and C. trubaniformis. Pumpkin is cultivated in tropical and temperate zones, mainly for its edible fruits but also for its leaves and seed plus its medicinal uses [33]. Pumpkin seeds are good sources of cooking and salad oils [33].

\section{Medicinal uses of Curcubita maxima}

Pumpkin seed oil has been reported to be useful in treating early stage disorders of the prostate gland and urinary bladder. It is believed to delay hyperplasia in ailing cells [34]. It has strong triglyceride and serum cholesterol lowering effects [34]. The constituents of pumpkin seeds are largely responsible for their health benefits. They contain significant amounts of protein, triterpenes, lignans, phytosterols, phenolic compounds,carotenoids, tocopherols, poly unsaturated fatty acids and antioxidants [35]. The seeds are diuretic [36], tonic, vermifuge and nervine [37]. The un-dehulled seed may be ground into flour, made into an emulsion and eaten. Afterwards, a worm expeller is taken to remove tapeworms or other parasites from the body [38]. The seeds are not as potent as the roots of Dryopteris felix-mas, but they are safer for pregnant women, and children [39]. The oil from the seed is used as a nerve tonic (39). The fruit pulp is used as a soothing poultice on burns, inflammations and boils [40]. Pumpkin is used in traditional medicine for several ailments: like the management of diabetes [39], anti-cancer [40], immunomodulation [41] antibacterial [41], antihypercholesterolemia, intestinal anti parasitia, anti-inflammation, and antalgic [41]. This review is focused on the main medicinal properties of the potential blood builders in relation to their content of iron and other micronutrient that are necessary for the formation of haemoglobin.

\begin{tabular}{|l|c|c|}
\hline & $\begin{array}{c}\text { Edible portion with- } \\
\text { out seeds and shell }\end{array}$ & $\begin{array}{c}\text { Edible portion } \\
\text { without shell }\end{array}$ \\
\hline Water $(\mathrm{mg} / 100 \mathrm{~g})$ & 89.2 & 55.0 \\
\hline Energy $(\mathrm{KJ})$ & 95.0 & 2331 \\
\hline Protein $(\mathrm{g})$ & $55-113$ & 23.4 \\
\hline Fat $(\mathrm{g})$ & 0.2 & 46.2 \\
\hline Carbohydrate $(\mathrm{g})$ & $2.2-4.4$ & 21.5 \\
\hline Fibre $(\mathrm{g})$ & $1.0-2.4$ & 2.2 \\
\hline Calcium $(\mathrm{mg})$ & $29-477$ & 57 \\
\hline Phosphorus $(\mathrm{mg})$ & $19-136$ & 900 \\
\hline Iron $(\mathrm{mg})$ & $0.4-0.8$ & 2.8 \\
\hline Beta carotene $(\mu \mathrm{g})$ & $450-3600$ & - \\
\hline Thiamin $(\mathrm{mg})$ & $0.6-16$ & 0.15 \\
\hline Riboflavin $(\mathrm{mg})$ & Trace-0.32 & 1.4 \\
\hline Niacin $(\mathrm{mg})$ & 0.1 & - \\
\hline Folate $(\mu \mathrm{g})$ & 10 & - \\
\hline Ascorbic acid $(\mathrm{mg})$ & $14-80$ & - \\
\hline
\end{tabular}

Table 6

\section{Composition of Curcubita maxima}

Table 5 highlights the chemical composition of Curcubita maxima. There are wide variations in the composition of different cultivars/varieties of this vegetable varies [42]. The wide variations in values observed by different researchers indicate varietal differences in nutrient composition as well as soil and planting conditions. The composition of pumpkin indicates that it contains reasonable amounts of protein [42]. Pumpkin seeds also contain considerable amounts of vitamin E. pumpkin seeds are a great source of protein and unsaturated fats, including omega-3. They also contain iron, selenium, calcium, B vitamins and beta-carotene.

\begin{tabular}{|l|c|c|}
\hline \multicolumn{1}{|c|}{$\begin{array}{c}\text { Plant } \\
\text { product }\end{array}$} & Medicinal Uses & Reference \\
\hline $\begin{array}{l}\text { Solanum } \\
\text { aethiopicum }\end{array}$ & $\begin{array}{c}\text { Diabetes, bronchitis, } \\
\text { asthma,dysuria,dysentery }\end{array}$ & Chioma., et al. [12] \\
\hline $\begin{array}{l}\text { Sida rhom- } \\
\text { bifolia }\end{array}$ & $\begin{array}{c}\text { Diabetes,inflammatory } \\
\text { disorders; rotenone } \\
\text { induced oxidative stress in } \\
\text { Parkinson's disease }\end{array}$ & Charturvedi [42] \\
\hline $\begin{array}{l}\text { Irvingia } \\
\text { gabonensis }\end{array}$ & $\begin{array}{c}\text { Weight loss, diabetes, } \\
\text { overweight, obesity, cho- } \\
\text { lesterol }\end{array}$ & Kuyoro., et al. [43] \\
\hline $\begin{array}{l}\text { Fiscus } \\
\text { capensis }\end{array}$ & $\begin{array}{c}\text { Promotion of vascular } \\
\text { health } \\
\text { Healing of skin sores }\end{array}$ & Chisembu [45] \\
\hline $\begin{array}{l}\text { Curcubita } \\
\text { maxima }\end{array}$ & $\begin{array}{c}\text { Urinary disorder } \\
\text { Improved liver function }\end{array}$ & Nishimura, [44] \\
\hline
\end{tabular}

Table 7: Summary of Evidence based Medicinal uses of Plant products in Different Traditional Settings.

The Dutch egg- plant and the pumpkin were found to be very useful sources of vitamin C (see Figure 2). The Dutch egg -plant arrow leaf and bush fig are good sources of vitamin A. The Dutch eggplant, pumpkin and bush fig are good sources of folic acid (vitamin $\left.\mathrm{B}_{9}\right)$

Vitamin Content of Traditional blood builders

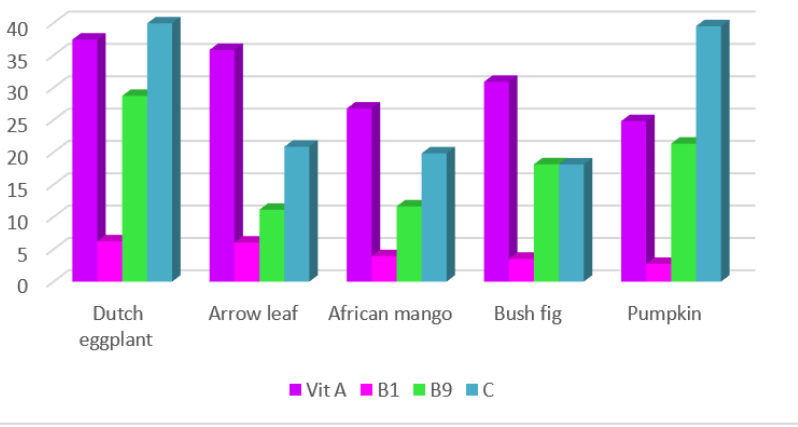

Figure 2: Vitamin content of the plant products perceived to be blood builders. 
Figure 3 shows that the Dutch egg- plant, arrow leaf and pumpkin are good sources of iron. Spinach from Iran contained significantly high amounts of iron $(99 \mathrm{mg} / 100 \mathrm{~g}$ ) [45]. (Zinc is required in very small amounts and while the zinc content of the arrow leaf exceeds the Recommended Daily Allowance (RDA) value of $0.8 \mathrm{mg} / 100 \mathrm{~g}$; the other plant products contain reasonable amounts of zinc $(0.62-0.77 \mathrm{mg} / 100 \mathrm{~g})$.

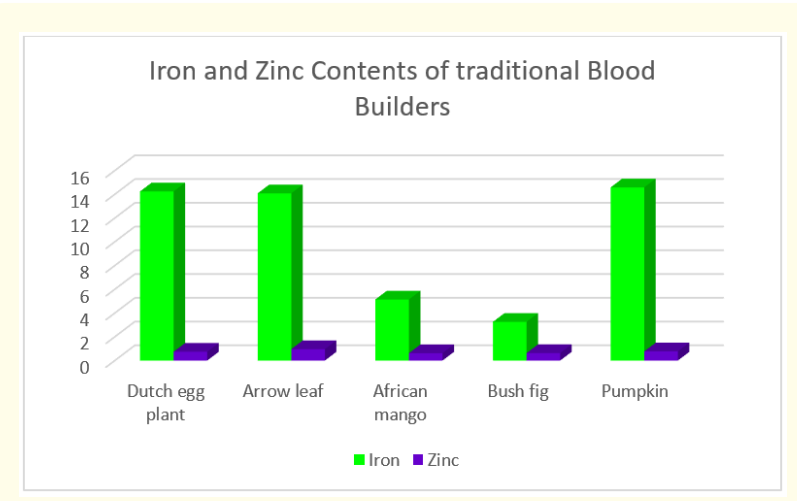

Figure 3: Iron and zinc contents of perceived traditional blood builders.

\section{Discussion \\ Plant products as blood builders}

Blood transports oxygen from lungs to body tissues. It transports nourishment after absorption to other parts of the body. It also transports hormones from glands, throughout the body. It transports antibodies to tissues and wastes to the kidneys. The red blood cells contain protein (four polypeptide chains, non -covalently bound to one another (globin) which are coordinated by iron. Iron is required for blood production. It is required for DNA synthesis. Seventy percent of the body iron is found the red blood cells and in the muscle cells. Six percent of the body iron is a component of some proteins, involved in respiration and energy metabolism; component of enzymes of collagen synthesis and some neurotransmitters. Iron is required in small amounts less than 100 mg per day) and constitutes, less than $0.01 \%$ of body weight Iron is required for proper immune function. Dutch egg- plant, arrow leaf and pumpkin are good sources of iron. The human body stores about $25 \%$ of its iron as ferritin. Adult males store enough iron to last about three years while adult females may have stores that can last for about 6 months. When iron intake is low over time, the iron stores become depleted and may degenerate to iron-deficient erythropoiesis and eventually iron deficiency anaemia. The adult minimum requirement of iron is $1.8 \mathrm{mg}$ per day. Only about $10-30 \%$ of consumed iron is absorbed. When the level of iron is low, haemoglobin is not synthesized in sufficient amounts and the oxygen carrying capacity of red blood cells is reduced resulting in anaemia. The body stores some iron in the bone marrow, liver, spleen, and skeletal muscle. In animal based foods, $60 \%$ of iron is bound to haemoglobin and haem iron is more biologically available than non-haem iron. Plant food contain non-haem iron and some plants also contain anti-nutrients that hinder iron absorption. Foods rich in vitamin $\mathrm{C}$ increases iron absorption. Trace minerals are essential in much smaller amounts, less than $100 \mathrm{mg}$ per day, and make up less than $0.01 \%$ of body weight. All the plant products contains the recommended daily requirement of zinc. Arrow leaf contains high amounts of zinc. Zinc is required for the formation of haemoglobin and diets that are deficient in zinc result in anaemia. Copper is a cofactor of enzymes involved with iron absorption and transport. Lack of copper in the diet can cause anaemia by reducing the mobilization of in the body for red blood cell synthesis. Minerals are better absorbed from animal based foods than plant based foods. Excess zinc in the diet can impair iron and copper absorption. Absorption of minerals is impaired in elderly people. Iron in four Iranian vegetables were Dill (104mg): Spinach (99mg); Parsley (110mg); Mint (210mg). The values indicate that these Iranian plants are very good sources of iron if they are biologically available.

Vitamin A is required for haematopoiesis. Vitamin A deficiency is often associated with iron deficiency anaemia. Improving vitamin A status will increase the utilization of iron [46]. Dutch eggplant and arrow leaf are very good sources of vitamin A> Serum retinol and haemoglobin concentration are significantly positively associated with serum iron and ferritin. Dutch egg- plant and the pumpkin were found to be very useful sources of vitamin C.

\section{Conclusion}

This paper summarizes current knowledge of morphological characteristics, general uses, medicinal uses and chemical constituents of five plant products used as blood builders in South Eastern parts of Nigeria. There is clear evidence that traditional uses of Solanum aethiopicum and Curcubita maxima are related to their status as functional foods that provide improved blood forming elements and promote oxygen transport. There is need to enhance viable seed production mechanisms and diversify the uses of these plant products in food systems in order to enhance the nutritional status of the populace.

\section{Conflict of interest}

The author has no conflict of interest to declare

\section{Funding}

This research was conducted using personal funds.

\section{Bibliography}

1. Wu AN., et al. "Screening for iron deficiency". Paediatrics in Review 23.5 (2002):171-178.

2. CDC. "Recommendations to Prevent and Control Iron Deficiency in the United States Centers for Disease Control and Prevention". MMWR Morbid Mortal Weekly Report 47.3 (1998): 1-29. 
3. ACC/SCN. "What Works? A Review of the Efficacy and Effectiveness of Nutrition Interventions". Geneva in collaboration with the Asian Development Bank, Manila (2001).

4. Hurrell RF., et al. "Iron fortification of infant cereals: a proposal for the use of ferrous fumarate or ferrous succinate". American Journal of Clinical Nutrition 49.6 (1989): 12741282.

5. Ross J and Thomas EL. "Iron Deficiency Anaemia and Maternal Mortality". Washington D.C Academy for Educational Development. (1996)

6. AOAC. "Official methods of Analysis.15th Ed, Association of official analytical chemists". Washington D.C. 808. (1990): 831835.

7. Voon BH., et al. "Wild fruits and vegetables in Sarawak". Department of Agriculture Sarawak (1998): 114.

8. Asian Vegetable Research Development Center (AVRDC) African scarlet eggplant. The AVRDC Nutrient Database. AVRDC - The World Vegetable (2004). Database Center. http://avrdcnutrition.gtdtestsite.comoj.com/nutrition/about.php

9. Calvo-Asensio., et al. "Vigor for in vitro Culture Traits in S. melongena S. aethiopicum Hybrids with Potential as Rootstocks for Eggplant". Science World Journal (2014): 1-8.

10. Bukenya-Ziraba R and Carasco JF. "Ethnobotanical aspects of Solanum L. (Solanaceae) in Uganda”. In: Nee M, Symon DE, Lester RN, Jessop JP (eds) Solanaceae 4: Advances in biology and utilization. Royal Botanic Gardens, Kew (1999): 345-360.

11. Lester RN Taxonomy of scarlet eggplants. "Solanum aethiopicum L". Acta Horticultura 182 (1986): 125-132.

12. Chioma A., et al. "Does the African garden egg offer protection against experimentally induced ulcers?". Asian Pacific Journal of Tropical Medicine 4.2 (2011):163-166.

13. http://www.who.int/vmnis/indicators/haemoglobin.pdf

14. Odetola AA., et al. "Hypolipidaemic potentials of Solanum melongena and Solanum gilo on hypercholesterolemic rabbits". Pakistan Journal of Nutrition 3.3 (2004):180-187.

15. Edem CA., et al. "A comparative assessment of the proximate composition, ascorbic acid and heavy metal content of two species of garden egg (Solanum gilo and Solanum aubergine)". Pakistan Journal of Nutrition 8.5 (2009): 582-584.

16. Pandanus database of Indian plants. "Sida rhombifolia". Natural Resources Conservation Service PLANTS Database. USDA. Retrieved 12 August, 2017. BSBI List 2007". Botanical Society of Britain and Ireland. Retrieved (2014): 10-17.
17. Herbpathy.com "The International Institute of Tropical Forestry (USDA) Forest Service, Sida rhombifolia L". Immunopharmacology Immunotoxicology 34.2 (2012): 326-36.

18. Parrotta JA. "Healing plants of Peninsular India”. CABI Publishing, Wallingford, UK and New York (2001): 917.

19. Shaman Australis Botanicals: Basement Shaman: Medicinal plants, herbs and mushrooms: basementshaman.com/

20. Narendhirakannan RT and Limmy TP. "Anti-inflammatory and anti-oxidant properties of Sida rhombifolia stems and roots in adjuvant induced arthritic rats". Immunopharmacology and Immunotoxicology 34.2 (2012): 326-336.

21. Prakash A., et al. "Alkaloid constituents of Sida acuta S. humilis, S. rhombifolia and S. spinose". Planta Medica 43.4. (1981) 384-388.

22. Anegbeh PO., et al. "Domestication of Irvingia gabonensis: 3. Phenotypic variations of fruits and kernels in a Nigerian village". Agroforestry Systems 58.3 (2003): 213-218.

23. Sulaiman AO., et al. "Evaluation of anti-diabetic activity of Irvingia gabonensis (Auby-Lecontw ex O'Rorke) leaf and bark in alloxan induced diabetic rats". Biosciences Research in Todays Work 1 (2015): 84-89.

24. Ogunsina BS., et al. "The proximate composition of African Bush mango kernels (Irvingia gabonensis) and characterization of its oil". Ife Journal of Science 14.1 (2012): 177-183.

25. Aina J0. "Physico-chemical changes in African mango (Irvingia gabonensis) during normal storage ripening". Food Chemistry 36.3 (1990): 205-212.

26. Keay RW. “Trees of Nigeria”. Claredon Press Oxford (1989): 287 298.

27. Seun FA., et al. "Aqueous extract from Fiscus capensis leaves inhibit key enzymes linked to erectile dysfunction and prevent oxidative stress in rat's penile tissue". Nigerian Food Journal 4 (2016):15-21.

28. Oyeleke BS., et al. "Antibacterial activity of Ficus capensis". African Journal of Biotechnology 7 (2008): 1414-1417.

29. Omonkhelin J0., et al. "Evaluation of Tocolytic activity of ethanol extracts of the stem bark of Ficus capensis Thumb (Moraceae)". Acta Poloniae Pharmaceu 66.3. (2009): 293-296.

30. Akomolafe SF., et al. "Aqueous extract from Ficus capensis leaves inhibits key enzymes linked to erectile dysfunction and prevent oxidative stress in rats' penile tissue". Nutrition and Food Science Journal 4 (2016): 15-21. 
31. Emeje MO. "Effect of two surfactants and mode of incorporation on the compaction characteristic of hot water extract of Ficus surforssak". Journal of Nutraceutical Functional and Medical Foods 4.3 (2004): 147-154.

32. Francois MN., et al. "Chemical composition and biological activities of Fiscus capensis leaves extract". Journal of Natural Products 3 (2010): 147-160.

33. Guha J and Sen SP. "Physiology, biochemistry and medicinal importance. In: Nayar, N.M. \& More, T.A. (Editors). Cucurbits. Science Publishers Inc., Enfield NH, United States. (1998): $97-$ 127.

34. Lal VK., et al. "Effect of Hydro-Alcoholic Extract of Cucurbita maxima, Fruit Juice and Glibenclamide on Blood Glucose in Diabetic Rats". American Journal of Pharmacology and Toxicology 6.3 (2011): 84-87.

35. Saha P., et al. "Antidiabetic Activity of Cucurbita maxima Aerial Parts". Research Journal of Medicinal Plant 5.5 (2011): 577586.

36. Doke PP., et al. "Central nervous system stimulant effect of the oils obtained from seeds of Cucurbita maxima". Journal of pharmaceutical Biology 1.1. (2011) 30-36.

37. Elhadi IM., et al. "Antigiardial Activity of some Cucurbita Species and Lagenaria siceraria". Journal of Forest Products and Industries 2.4 (2013): 43-47.

38. Kiranmayi GVN., et al. "Phytochemical Screening and In Vitro Comparative Study of Anthelmintic Activity of Asparagus racemosus and Cucurbita maxima". Journal of Pharmacy Research 5. 3 (2012): 1545-1547.

39. Patel H., et al. "Evaluation of anti-inflammatory activity of Cucurbita maxima fruit". Journal of Advances in Pharmaceutical Research and Biosciences 1.1 (2013): 28-31.

40. Prerona S., et al. "Anticancer activity of methanol extract of Cucurbita maxima against Ehrlich ascites carcinoma". International. Journal of Research in Pharmaceutical Sciences. 2.1.(2011): 52-59.

41. Kabbashi JAS., et al. "In vitro amoebicidal, antimicrobial and antioxidant activities of the plants Adansonia digitata and Cucurbita maxima". Advancement in Medicinal Plant Research 2.3.(2014): 50-57.

42. Chaturvedi P and Kwape TE. "Attenuation of diabetes conditions by Sida rhombifolia in moderately diabetic rats and inability to produce similar effects in severely diabetic rats". Journal of Pharmacopuncture 18.4 (2015): 012-019.
43. Kuyooro SE., et al. "Hypolipidemic effects of Irvingia gabonensis-supplemented diets in male albino rats". Biochemistry and Analytical Biochemistry 6.2. (2017).

44. Nishimura M., et al. "Pumpkin seed oil extracted from Cucurbita maxima improves urinary disorder in human overactive bladder". Journal of Traditional and Complementary Medicine 4.1. (2014): 72-74.

45. Chisembu KC. "Ethnobotanical study of plants used in the management of HIV/AIDS related diseases in Livingstone province, Southern Zambia". Evidence based complementary and Alternative medicine Article ID 4238625, 14 (2016).

46. International Vitamin A Consultative Group. IVACG. Vitamin A and iron interactions. International Vitamin A Consultative Group. IVACG the ILSI Research Foundation's Human Nutrition Institute. USA.

\section{Volume 3 Issue 8 August 2019}

(C) All rights are reserved by 0 jimelukwe $\mathrm{PC}$. 